\title{
Whence the cimmerians came? transcontinental communications of the early nomads in the lights of the origin of the cimmerians
}

\begin{abstract}
Eurasian communication of the Early Nomads determined the main cultural and historical processes in the Ancient World, combining with each other remote regions and civilizations, forming a branched of the trans-continental channels of distribution excellence, inventions of various goods, which in turn stimulated the evolution, development and production of its own vehicles. This assertion is based on a detailed analysis of the relevant written, pictorial and archaeological sources; on the facts, argue the hypothesis of the origin of the Cimmerians $^{1}$ of the inland areas from Central Asia, as well as based on the evidence of widespread use of chariot and cavalry. The author identifies the historical Cimmerians with carriers of Karasuk archaeological culture and its derivatives.
\end{abstract}

Keywords: Communications; Wheeled transport; Asian chariots; Karasuk culture; Cimmerians; Sakas; Xiongnu; Persepolis; Ecbathanae; Pasargadae; Akhemenid empire; Darius the great; Cyrus the great; Qin empire; Qin shikhuang (Di); Pasyryk culture; North eurasia; North pre-black sea, Central asia.
Volume 3 Issue I - 2018

\author{
Viktor A Novozhenov \\ Senior Researcher, UNESCO Center for the Raproachment of \\ Cultures in Almaty, Kazakhstan
}

Correspondence: Viktor A Novozhenov, Senior Researcher, Department of International Co-operation, UNESCO Center for the Raproachments of Cultures, Kazakhstan,

Email vnovozhenov@gmail.com

Received: May 26, 2017 | Published: January 10, 2018

${ }^{1}$ Because of the Cimmerian problem in the literature published by a huge amount of material, the author did not initially aims to analyze in detail within the framework of this brief article by numerous archaeological findings on this topic. Here we present an extensive bibliography and detailed references to these publications by means of which the interested reader will always find the right information. In this article, we have paid more attention in the literature expressed concepts of archaeologists in this regard, as well as written and pictorial sources, which in our opinion, were less involved for understanding this complex puzzle of ancient history.

\section{Introduction}

At the time, Prof. Kemal Akishev drew attention to the considerable similarity of European Scythians culture and Asian Sakas, ${ }^{1}$ thus laying the foundation for the study of their transcontinental communications. Indeed, the very nomadic ordained main areas of communicative activity of Early Nomads in the entire Eurasian steppe zone. Cultural and economic type of their life estimated duration (in essence migration) of all its society-clan (group of blood relatives), length often several thousands kilometers cyclical, i.e. the inevitable return to their original territories; vertical nomadism in the fertile mountain pastures and many other features. ${ }^{2}$

New communication arose originally as a natural result of the formation and successful functioning in the vast territories of bureaucratic imperial infrastructures. They were determined and various internal factors emerging in these spaces societies (ethnic groups), their unique identity and external, including marriage and family ties. Priority in nomadic societies of both verbal and figurative (visual) communicative tradition, as opposed to writing, as explained by the mobile way of life, despite the fact that there were already quite complex patterns of sign communication. Thus, writing in the nomadic fixed monuments of Zhetysu's Sakas ${ }^{3}$ and it seems that it is now close to the reading of. ${ }^{4}$ Saka-Scythian animal style, its decoding and spatial distribution in the synchronous monuments in the vast territory of the continent a vivid testimony to the development of transcontinental, as a matter of fact the iconic and imaginative communication of Early nomads in this period. The phenomenon of the origin of this style ${ }^{5,6}$ and its geographic distribution, decoding the images and messages of communication an independent research topic, far beyond the scope of this article.

The format of this work involves the analysis of only certain aspects of the communications of the Early nomads of Eurasia and is dedicated to attempts to compare the data of some sources: linguistic, visual and archaeological, in order to support in a working hypothesis of possible solutions to the problem of the origin of the Cimmerians as a carriers of Karasuk archaeological culture. This issue is already on the minds of many generations of scientists and the concept of the origin of the inland areas of Central Asia (the so-called Junggar or Central Asian hypothesis) finds more and more supporters. ${ }^{7-14}$

\section{Written and pictorial evidence}

A curious situation recorded ancient cuneiform documents Assyrian and Neo-Babylonian Empire VII-VI cent. BC. In the Babylonian literary tradition word Cimmerians describes, as a rule, all known to the Babylonians the nomadic peoples of the country: the Scythians, Sakas and, obviously, the actual Cimmerians and their country Gumiraia. ${ }^{15,16}$ In Assyria of VII cent. BC term Cimmerian (gumirayia) opposite used as the name of two independent nation, along with the Central Asian Sakas-ayshkuzayya: haumavarga, tigrahauda and paradrayya. ${ }^{15,17}$ At the same time the Assyrians in direct contact with the steppe peoples and better the Babylonians knew its steppe neighbors. For this reason, we feel rather strange widespread in the scientific literature review on the Sakas tribes circle as the main and almost sole dwellers in the steppes of Eurasia came from the depths of Asia, who actively collaborated with Assyria, Persia and the ancient Greeks. In written documents of Achaemenid's times 
mentioned and other Central Asians Areies, Caspians, Bactrians, Sogdians, Khorezmians, Gandharians and others who, like Sakas, obtained from the imperial administration allotments, called earth bow (or the chariot / or a horse) and carried conscription, regularly paying state taxes. ${ }^{15,16}$

Just look at the well-preserved stone reliefs and read the inscription stairways ruins of the palace of Persepolis Apadana or Takhara, which ceremoniously passed the procession and the conquered peoples subordinate Achaemenids. ${ }^{18}$ Detailed displayed anthropological and cultural differences tributaries come from the remotest corners of the vast empire, from its various satrapies, their specific gifts as tributes brought by the Persian kings. The composition of many peoples conquered by the Persians, were part of the Achaemenid Empire, was captured in the inscription of Darius the Great on the rocks in Besetune (or Bestune: so-called Behistun inscription); there is such a list directly on the statue of king Darius the Great, exhibited in the exposition of the National Museum in Tehran. Also lists the nations represented in other sources, such as cylinder of Cyrus the Great in the British Museum.

However, the earliest mention of the nomads of the Eurasian steppes appear in the second half of the VIII cent BC. Their military campaigns in Southwest Asia began no later than 714 BC., when they are first mentioned in Assyrian documents and continued, apparently, during the VII cent. BC. ${ }^{17}$ Previously, all the steppe in the Near East came Cimmerians, who repeatedly have made successful military raids on ancient Middle Eastern countries, subdued Lydian and Phrygian kingdom, acted as allies or mercenaries on the side of both Assyria and Urartu in their irreconcilable rivalry between them and the final of expulsion from Asia is attributed to the Lydian king Alyattes. New invasion of Scythian troops put an end to the Cimmerian invasion and some part of them joined the association Scythian tribes. ${ }^{14,17}$ Cimmerians, unlike Sakas, never were vassals of the Assyrian, Urartu, or the Persian kings and considerable time is itself a formidable military union, ${ }^{15,19}$ so powerful, that the Greek colonists in Asia Minor (Miletus) had to be built to protect against a rather complex system of fortifications..$^{20}$

Perhaps to protect against such military organizations far to the east of the continent built the Great Wall of China's first emperorunifier Ichzhen (Qin Shikhuang) and its predecessors wans of northern states that are more likely to confirm earlier, Dynasty Xia and Shang in ancient Chinese inscriptions fortunetelling on bones (sheep's scapula and tortoise shells) found in the amount of several thousand in the northern and western provinces of China. They clearly demonstrate a real and constant northern threat, an active contact with the steppe population comes from the north and northwest These steppe nomadic clans could be tribes inhabiting gui-fan, gunfan, in the State of Yan (one of the principalities of Western Zhou), which Shang and Zhou rulers constantly waged wars. In general, the following is recorded toponimy ${ }^{1}$ located in the north and north-west of the Central Plains of China tu-fang, kiwei-fang, giwon-fang and ngo-fang. ${ }^{2,21-25,}$ It is noteworthy that the earliest sources described all northern neighbors, the ancient Chinese riwem (rong), they are also in Russian transcription zhuns (zhuns-northern and mountain), which

${ }^{1}$ Countries subordinates or bordering with China, traditionally called possessions China fan (fang).

${ }^{2}$ In a special article Dr. A. A. Kovalev examines in detail the well-known ancient Chinese ethnonims neighbors and cites numerous interpretations of options for transfers from different sources. Special attention should be given to them in ancient Chinese chronicles mention interest period of the iconic belt plaques, which are actively used nomads northern neighbors of the Chinese in the period of the Western Zhou and later. literally means: warrior, war chariots, a large military campaign. It is noted that this term is not an ethnonym and is the common name for all the neighbors. The Shang fortunetelling inscriptions on bones and bronze vessels as referred to in the ethnonyms and other concepts: eastern yek (yei), northern ti - (tieks), western rivem (zhuns, jungs). ${ }^{21}$

Insufficiently reasoned opinion submitted by Dr. A Khodzhaev that rivem (rong, ron) and tiek (ti-di) different names are not two separate ethnic groups, as one people. These links to their military campaign of Jong-wang (1024-1005 BC), captured the leaders of the tribe tiauk (tiek) submitted incorrect and he referred to the military campaign took place much later the first known mention of rivems, as, however and said the author information from later sources.

It is more logical to assume the existence at an early stage, at least two different ethnonyms: rivem (and its derivative forms) earlier and tiauk (ti-di-tiek) later describing the related, but already ethnically diverse peoples. Furthermore, the author himself cites the opinion of Van Gouvei mention ethnonim tiek (di) on metal vessels of Western Zhou period and it is used frequently in later written sources of VI cent. BC with its subsequent transformation into hu and xiongnu (hun) ethnonyms which has likely designated ancestors of turkic peoples. ${ }^{21,23}$

In her studies, Kathrine Lindaff ${ }^{26,27}$ on the basis of territorial distribution of Siberia, Kazakhstan and Altai's weapons and metallurgical tradition, consistently proves the existence of significant and developed communication between the steppe tribes of the north and the population of the Central Plain of China for a long historical period. Across the northern and north-western border there were new settlements trading posts (factories); steppe women became wives, came to the houses of the local Chinese (Chinese right?), bringing everyday objects, their traditions and customs. Many factors have kept for centuries the material culture of the northern nomads virtually unchanged, without any notable was the influence of traditional Chinese culture. ${ }^{28-29}$

Leo Klein ${ }^{30,31}$ rightly believes that the ancient Chinese knew north from three Europeoid people: usuns (asia) yuedzhi and di (liok), while it permits on the basis of borrowed Chinese in terms that someone of them may be Tochars. ${ }^{30,31}$ The data confirm the use of linguists in Central Asia ancient language of Indo-European root Dardic, Kafir, Tocharian and Indo-Iranian languages of the Rig Veda and Avesta. It is likely that the ancestors of Usuns and Yuedzhi may be Andronovo's and Di (tieks) Karasuk's peoples. Prof A Suleimanov supports the view of S Kiselev ${ }^{32}$ about the Türkic types of di-(dinlins) direct heirs of Karasuk culture and traditions, following the Chinese sources, defines ethnonyms types (di) and dinlins later the body as different forms of ethnonyms ancient Turkic-speaking tribes. ${ }^{3}, 33$ This idea is being actively developed by some contemporary türkologists..$^{34,35}$

Whatever it was, going back to the sources of the Near East, it is impossible to ignore the documented facts written tradition of borrowing by the Assyrians and Babylonians already in VII cent. BC the belts, bows and arrows by Cimmerian type of horse and military equipment, the Cimmerian Shine and later (since New Assirian and Neo-Babylonian times) Sakas special peaked hats for the riders. ${ }^{15-17,36,37}$

Indicative in this sense, we present some economic documents the times of Nebuchadnezzar II and Nabonidus. One of them, compiled in $564 \mathrm{BC}$ says: Cimmerian leather straps (are) at the disposal of

${ }^{3}$ Representatives of the proto-ethnic group in our understanding. Linguists point out significant similarities the Indo-European languages and Altaic families and emit many common roots of words and tokens (up to $90 \%$ similarity!) in PIE (early indoeuropean-boreal after Prof. N.D. Andreev) language. ${ }^{44,45}$ 
horses overseer Rimuta. In a private letter contains a request to send Cimmerian belts in another document a list of clothing, fielding eight archers carrying guard duty, which, inter alia, referred to 116 Cimmerian reed arrows (of which 46 - with iron arrows and the rest with bronze), 56 Akkadian arrows, one Cimmerian bow (along with Akkadian bows) and spears, daggers and shields. ${ }^{15}$ All documents indicate the ownership of these Cimmerian belts or to horse equipment, or to outfit soldiers. In written documents also recorded the names of the first three kings of the Cimmerian, the origin of which can not be reliably determined from the Iranian roots. It is possible their nonIranian, Anatolian or composite origin. ${ }^{17}$

\section{Archaeological sources}

How do the foregoing linguistic data with archaeological finds and dating? According to most researchers, historical monuments identified Cimmerians with Chernogorovsk and Novocherkassk cultures of Eastern European steppes. ${ }^{11,38,39}$ Despite criticism of this concept, ${ }^{17,40}$ a sound is not currently proposed. ${ }^{12,14,41}$ The current state of research Antiquities of Cimmerian by SV Mahortykh ${ }^{42}$ described in, which contains evidence of a link with historical Cimmerians as carriers of Chernogorovsk and Novocherkassk cultures. ${ }^{43}$

A Terenozhkin ${ }^{11}$ defined chronological framework of Cimmerian culture within 900-650 BC, while stressing the two successive stages of its development Chernogorovsk approx. 900-750 BC and Novocherkassk 750-650 BC. Obtained as innovations in material and spiritual culture associated with this alien population: ${ }^{4} \mathrm{~A}$ strong tradition of bronze casting production of new high-quality weapons ${ }^{5}$ primarily knives and daggers of Karasuk type bladed bronze socketed arrowheads with rhombic or keeled head. ${ }^{11,14,46-48}$ Types of horse bridles, similar to Arzhan's: bronze or bone three-holes cheekpieces spaced along the edges of side holes and the two-parts bits with missing protrusions on the edges of the loop ${ }^{11,12,14,49}$ Cimmerian anthropomorphic stele, possibly originating from the Central Asian deer stones. ${ }^{50-54}$ Prof V Murzin links the origin of the Cimmerians with the penetration of groups of early nomads in the northern Black Sea region, people from the eastern regions of the continent and mixing with the local Iranian-speaking tribes Belozersk native culture of the Late Bronze Age. ${ }^{11,17}$

Such an understanding of the origin of Antiquities Cimmerian support some other researchers. So, Konstantine Chugunov, developing the concept of Prof. Alexandr Terenozhkin, combines in a single chronological layer of Arzhan-Chernogorovsk antiquity, attributing to him the earliest monuments of Biykentsk culture of Altai and Early Tagar's monuments of Podgornovsk stage in the Minusinsk Bassin, as well as synchronous from neighboring regions. ${ }^{12,55,56} \mathrm{We}$

\footnotetext{
${ }^{4}$ This opinion by Prof. Alexandr Terenozhkin is not currently supported by all researchers

${ }^{5}$ The basis of this technological tradition of investment casting wax and a high content of tin as an additive (ligation), the use of which in stone or clay molds manufacturing technology enables the production of complex configurations. Significant progress in the use of this technology have Seima-Turbino, Karasuk metallurgy and ancient Chinese during the Shang and Western Zhou in the production of cast bronze vessels, bells, masks tao-te, jewelry and complex forms of weapons. Details such technology and the spread of metallurgical traditions of the continent recently considered by Dr. Stanislav Grigoriev. Author directly links the spread of the technology solely for the movement of its regional carriers. "Movement" of the metal in Eurasia and the emergence of "the phenomenon of nomadic cultures" described in detail by Prof $\mathrm{E}$ Chernykh ${ }^{46}$ and in some of his earlier works. ${ }^{58}$ Metalworking technologies, traditional techniques discussed in detail recently by Dr. R Minasyan. ${ }^{48}$
}

believe that the origins of the Cimmerians, perhaps rooted in Karasuk antiquities.

\section{The origin of the karasuk culture}

The main monuments of this type mounds are very rare settlements and cult objects are located mainly in southern Siberia, East Turkestan, Mongolia and North China (Ordos). The entire suite of archaeological cultures Karasuk appearance: Elovsko-Irmensk (Western Siberia, Altai, Southern Urals), Begazy-Dandybay and Dongal (Central Kazakhstan), Early Tagar, Biykensk (Altai, Minusinsk Basin), AldiBelsk, Mayemirsk (Sayano-Altai), culture of Khereksurs and Deer stones (East Turkistan, Mongolia) live up to VIII-VI cent. BC.

Most of the carriers of these cultures and cultural traditions united as part of a powerful military-political union in the Central Asia Arzhan's Tribal Alliance, ${ }^{57}$ formed on the territory of Tuva, Altai and northwestern Mongolia. The term suite of karasukoid cultures we are quite arbitrarily combine different in their characteristics archaeological materials of the Befor Sakas time, perhaps a chronological horizon, which, in our opinion, clearly shown single metallurgical tradition allows for bronze weapons certain types of hollow sleeve and certain products from more durable metal ferrum (iron). ${ }^{6}$

The property itself dates back to 1440-1130 Karasuk culture (1450-1050 BC) and is synchronized with the period of the reign of ancient Chinese Shang Dynasty, radiocarbon dating is somewhat different with the dynastic chronology. According to radiocarbon dating a period of $1700-1050 \mathrm{BC}$ or the $1600-1046 \mathrm{BC}$ the results of comparing the radiocarbon and dendrochronological scales. Probably with the accumulation of the series will take place some narrowing of the interval and the two systems will be harmonized better. ${ }^{59}$ Modern views on the formation of the culture, history, the stages of its development in detail in the works of P Lazaretov ${ }^{60}$ and A Polyakov ${ }^{61}$ and other researchers. $7,12,62,63$

Traditionally considered the two main concepts of the origin of the Karasuk culture autochthonous ${ }^{9,10,32,64,65}$ and the migration. ${ }^{7,8}$ Moreover, all the researchers are unanimous in the opinion that it is bright and unique culture, is fundamentally different from her previous Eneolithic cultures. ${ }^{66}$ Divide by autochthonous and migration concept is rather conditional, since supporters of both hypotheses recognize the nomadic nature of this culture and do not exclude the migration of some of the clans its carriers. The differences lie in understanding the genetic basis of this culture and direction of local movements.

Prof. Sergay Kiselyov ${ }^{32}$ believed that the appearance of the Karasuk culture in Southern Siberia due to the influx of a new population of the south-east of North China. Prof. Mikhail Gryaznov ${ }^{64,66}$ defines it as a purely South Siberian phenomenon occurring from Andronovo

${ }^{6}$ We share here the two concepts of "karasuks" and "karasukoids", based on sociobiological factors ${ }^{58}$ because the latter are derived from the first - "parent" lines of ethnicity in the early stages of its formation with a different geographic location created by the cyclical migrations of these clans. Karasukoids probably are direct descendants of karasuks. Russell in search of new pastures over large areas of the continental steppes, foothills and perceiving through their wives' new elements alien to the spiritual and material culture, to develop their own identity within their clan or community themselves. The time frame of the process defined by a single chronological formation (cultural horizon), dated within the IX-VI cent. BC.

${ }^{7}$ We do not assume here a detailed analysis of Karasuk archaeological materials contained in these works as part of this brief article, focusing only on the reader's conceptual findings in the study of the history of this vibrant culture. 
monuments. Prof Heleonor Novgorodova, ${ }^{10}$ based on statistical methods of processing materials, has come to the conclusion that among the tribes of Mongolia, Tuva and Southern Siberia in Karasuk time there was an ethnic connection, the cause of which in a great migration wave swept from the mountain-steppe regions of Central Asia in the north-west side of the Yenisei River and to the west of Mongolia. ${ }^{32}$ At the same time, expressed the concept could not explain the origin of the skills development of metal processing and production of bronze, characteristic of Karasuks as its own development and earlier time-bronze casting tradition in China and in Mongolia is not fixed.

Dr. Natalia Chlenova attempted to remove this contradiction and to associate the origin of Karasuk metal with Louristan bronzes of Iran. She assumed penetration of Karasuk elements from Iran through Afghanistan and Xinjiang in Mongolia and then in southern Siberia, Tuva, North China, Trans-Baikal region (from west to east of the continent). Another branch of the Karasuk community, in her opinion, was distributed to the west, up to Central Europe. ${ }^{7}$ However, it soon became clear that the Louristan bronzes can not be dated before the XII cent. $\mathrm{BC}^{67,68}$ and some of the findings were simply fakes in Ziwiye. ${ }^{69}$ Prof. Heleonor Novgorodova ${ }^{10}$ the concept of criticism, rightly pointed out that animal style in the Zagros Mountains appear with established canons and forms that are not associated with the traditional images of animals in Iran. Of fundamental importance in this story are identified by Natalia Chlenova areas of spread of the Early Karasuk daggers. ${ }^{8}$ The most archaic daggers, according to its typology found in the Minusinsk Basin, Ordos and Inner Mongolia, as well as in the Middle East, the Caucasus and northern Iran. Daggers similar type presented by findings from East and Central Kazakhstan and on the west from the steppe Trans-Urals (Bashkiria). There are daggers unit of this type in Ukraine, up to the North-Western Black Sea.

We believe that after the Natalia Chlenova and Leo Vasilyev that Karasuk and Shang culture genetically traced back to some third, still insufficiently known bronze culture. ${ }^{70,71}$ Surely this could be the basis of metallurgical bronze casting tradition, recorded in the monuments of Seima-Turbino transcultural phenomenon. ${ }^{72-77}$ Seima-Turbino finds, first of all weapons: spears and daggers, apparently made clans professional master-metallurgists, media kind of metallurgical traditions mediate (in the developed stage) between two other large groups Andronovo and Karasuk, supplying and those and other most modern types of weapons from a hollow bronze bushing. The sacred nature of the profession and the blacksmith caste known for ethnographic data in almost all nations of the world and Seyma-Turbino products are widely presented in Andronovo monuments. ${ }^{13,47,78-82}$

\section{Weapons complex of early riders}

Most clearly this metallurgical tradition socketed cast emerged and continued later in the production of weapons Before and Early Sakas time in the northern regions of Central Asia. Prof Yuly Khudyakov ${ }^{83-85}$ in a number of his papers ${ }^{83-85}$ examines in detail the features of the formation of weapons complexes of Early nomads in the numerous examples of the monuments of the Sayano-Altai Aldy-Belsk and Maemirsk cultures within the already mentioned previously Arzhan's Tribal Alliance, which are relevant for the adjacent territories of Kazakhstan. ${ }^{55,56}$ Analysis of these weapons material by Prof. Yuly Khudyakov ${ }^{83-85}$ leads to the conclusion that the ancient nomads of Tuva (Aldy-Belsk culture) at this time significantly superior to the neighbors (Mayemirsk representatives of the cultural tradition of Altai) in terms of the used iron-smelting technology. They have succeeded in creating a centralized military structure and within the tribal alliance Arzhan subjugated many neighboring Altai tribes. ${ }^{85}$

Chariot set of weapons in this period transformed: there are a number of innovations related to the start of the active use of iron and horses under the top, which caused in turn, change the battle tactics and weapons of the complex. It was a set of arms is not charioteer and a rider on a horse, ${ }^{85}$ which now consisted of: bows and lit with a two-blade socketed bronze and bone trihedral (Cimmerian (?) $\mathrm{VN}$ ) arrowheads, daggers, battle-axes with long handles with vtoks at the lower end, axes, rarely spears, bronze helmets and probably woven from twigs light panels for the riders of a later period (Berel, reconstruction by Krym Altynbekov ${ }^{86}$ ) and covered with a thick bull leather shields for infantry. ${ }^{87}$ The use of this weapon system during the battles led to a change of tactics of the battle: the mobile squads of lightly armed cavalry skirmishing fire at enemy troops to remotely attack the lava and practice with the defeat minted (at least - spears) in the near equestrian battle.

\section{Status lap belts and deer stones}

It seems that the repeated mention in written sources Cimmerian belt shows their obvious religious significance in society. They are listed as a specific ethnic and social sign, a kind of fashion trend, using modern concepts. Sources tell about their exclusivity, a close acquaintance to manufacture them with the skills to master the care of horses and methods of control animals on horseback or in a carriage wheel. In all of these sources, Cimmerian belts are mentioned only in the context of military uniforms, or as part of a horse harness. Perhaps these straps are connected not only with the horse harness, but also directly with the outfit belts warrior horsemen or charioteers, functional, symbolic and sacred meaning of which is already well described in the literature. ${ }^{86,88-90}$

Numerous finds remnants of status double belts are ubiquitous in the archaeological sites Scythian (Befor-Scythian) time on the Eurasian continent and made the reconstruction of these findings, compare them with the pictorial sources and experimental test of their functional purpose prove that they are traditionally used by nomads, in addition to its direct purpose and also for a comfortable fit (suspension) and if necessary the use of different types of weapons associated everyday objects, as well as in communication purposes to demonstrate their own social status. ${ }^{86}$

For horsemen, besides the above advantages, this belt is absolutely necessary and even as a rigid fixation of the waist and internal organs in a significant shaking and lack of adequate depreciation chariots. In full it is also true for both riders and charioteers for other types of carts; confirmed discoveries in the tomb of Tutankhamun the famous amateur riding a chariot, where alongside his crew found disassembled special clothing long strips of fabric that are very tightly wrapped around their travels around the body of the pharaoh in the area of the waist, chest and fixed like a semi-rigid body korset ${ }^{8}$. Operable model yoke as the belt buckles for remote control of the chariot to free the hands of the charioteer archery or the use of other weapons during the

${ }^{8}$ Kit charioteer also included special gloves for comfortable and reliable hold of the reins in his hands. They are also found in the tomb of Tutankhamun. Details of the story is perfectly reflected in the Corporation BBC documentary series, which tells about modern research of this unique burial of the young pharaoh chariot taken followers by archaeologist Howard Carter. 
battle has already been proved their location in Karasuk graves and ancient Chinese chemakyns in situ. ${ }^{9,84,91-94}$ We do not exclude the use of such plates and the front fence of the body as the chariot of hooks for tying the reins to them chariots. However, this is only possible in later designs of chariots: there is still no evidence of the use of such barriers in the early chariots, dated the first half of the second millenium BC. Anyway, we know iconic monuments and the remains of the crews in the most excavated graves of Early period of the Shang Dynasty show open platforms, without any trace of handrails or high fences (boards), where there was a charioteer who was constantly held in an upright position while on the platform and move balancing on ${ }^{94-96}$ It was, of course, an individual carriage and riding on it was a serious test. Charioteer maintain its position on this mobile platform on wheels sheer force of the tension of the reins the chariot, the fixed position of feet on the platform with special straps (Gotszyazhuan necropolis) own skills and trick riding. The art of managing a chariot, according to ancient Chinese chronicles (Shih Tzu), considered a very dangerous occupation, led to frequent falls chariots and breakdowns require the highest skill, serious driving skills and long training. ${ }^{97}$

Therefore, we believe that only the most appropriate way of fixing plates on the human body only a leather waist belt in the abdomen. The second belt of this belt sword belt fastened charioteer melee weapon a dagger, check, as well as suspended quiver and / or grindstone The fastening of the buckle on the belt in the case of tying allows its chariot reins, comfortable enough to drive a chariot and quickly by simply turning the housing in the right direction. The hands remain free chariot archery, javelin, placed usually in the rear of the crew, or to use any type of melee weapons hung from his belt. This way of remote control chariot when the reins tied around waist of charioteer and his hands are free for archery, well known for his paintings of ancient Egyptian chariots rushing into battle compositions and hunting scenes, where the pharaohs and nobles Egyptians exactly manage their crews.

If this is true, it becomes clear standard image on Karasuk deer stones weapons of various types and forms, clearly suspended from the belts depicted in these characters. This kind of pictorial sources ${ }^{54}$ can be considered as a kind of ethnic marker. Geographical distribution of anthropomorphic steles far to the west of the continent be mapped to promote themselves carriers of this tradition. ${ }^{9}, 52,53$ In our view, this type of Karasuk tribes actively developed this megalithic tradition installation of anthropomorphic stone sculptures (deer stones - Cenotaph) complexes such peculiar cult of honoring soldiers horsemen ancestor aruahs ${ }^{99}$ in conjunction with the very recognizable Karasuk pictorial tradition, dedicated to the petroglyphs on the rocks. ${ }^{93,100}$

\section{Dating}

Based on the above observations, the proliferation of images and the actual finds of real chariots, their production technology and associated set of arms, related cultural traditions: the actual tradition of making themselves chariots, as well as megalithic, pictoral, metallurgical; learning management skills chariots and distribution of a special social status of their respective owners, no doubt, allow to clarify many ethno-cultural and communicative processes during

${ }^{9}$ We strongly oppose the allocation by Dr. Alex Kovalev the culture of Deer stones, but fully support the conclusions of the two different traditions ${ }^{98}$ in their origin and the territorial extension to the west of the continent, in South Siberia and Kazakhstan). ${ }^{97}$ The idea of these complexes as a cenotaph in our view the most likely correspond to the historical reality. ${ }^{99}$ this period and become sufficiently reliable guide in the chronology of events and processes of formation of communication of the Early nomads.

The earliest graves with chariots (chemakyns) is traditionally dated in the early periods of Chinese historiography of the Shang Dynasty. In general, a series of dates Shang chemakyns quite heterogeneous. ${ }^{94-96,101-103}$ Materials from Syaomintun, Dasykuntsun can be attributed to the average period of the Shang Dynasty, radiocarbon dated 1750-1400 BC. Calibration of these dates for dendrochronological scale determines the upper limit of no later than 1550-1520 BC, which is consistent with the dating of the Shang chemakyns by other researchers. ${ }^{104-106}$ This is despite the fact that the earliest two-horse chariot on the Eurasian continent for the first time appeared in the northwest of China, in the Ural-Kazakhstan steppes, much earlier at the turn of the III-II mill. BC ${ }^{72,97,107}$ and most likely, it is in those places invented as a form of arms and the revolutionary military and economic innovation. ${ }^{108,109}$

Refine Zhou's finds dating allows rod-shaped horn cheek-piece (psalii) in the cemetery Bayfu, calibrated radiocarbon dates back to $1120(+/-90) \mathrm{BC}^{22}$ or $1085+/-130$ BC.This Western Zhou period burial has pronounced features of the steppe the similarity of the materials. Necropolis Lyulihe it relates to the already mentioned above the ancient state of Yan in North China, which was, according to archaeological and written sources, active contacts with Late Shang population of the Central Plain of China and with the tribes of the steppe and foothill regions of Central Asia. It is noteworthy that as money in this state used Karasuk knives. ${ }^{10}$ Established and published radiocarbon dating of Bayfu does not coincide with the data of traditional Early Chinees chronicles, which recorded the migration of Yan population of Henan Province in the province Hebey ${ }^{11}$ only during the reign of Cheng-wang in 1024-1005 BC, that may indicate a permanent earlier and later migrations of the steppe nomads on this territory and the existence of a permanent channels of communication.

Necropolis Shantsunlin associated with the ancient Go kingdom, which was destroyed by another state Jin in 655 BC. According to the inscriptions on the vessels of this repository established real officials of the State, who lived in the time of Wang Xuan, who ruled in 827782 BC. In general, this monument dates back to different times within the second half of the IX - first half of VII cent. BC, which also contradicts radiocarbon dating. Necropolis Chzhantszyaopo dates back to the reign of Cheng Wang and Kang Wang (1004-967 BC) and dated within the end of XI - the first half of the X cent. BC. Parameters dating of model yoke are defined as follows: are the earliest examples of a large grave in Uguantsun (Shang dynasty, second phase of Dasykuntsun) and the tomb of Fu Hao. ${ }^{106}$ These tombs are dated by radiocarbon $(1255(+/-160) \mathrm{BC})$, but this date requires an adjustment of dendrochronological scale, that in any event it determines Karasuk time.

Models yoke spread in the monuments of the Central Plain of China, dated X-IX cent. BC. In the northern regions remained

\footnotetext{
${ }^{10}$ However, such a "currency" was also circulated in some other neighboring countries to the north in the Warring States period before the unification of China's Qing emperor Shi Huan-di and even much earlier. Individual images of karasukoids knives life-size carved on the rocks among petroglyphs Maimak sanctuary in southern Kazakhstan, which also speaks in favor of their particular sign and communicative function.

${ }^{11}$ On the territory of this province is a modern city of Beijing, in the vicinity of which excavated burial Bayfu
} 
relatively primitive form of these products, which is quite late reaches Minusinsk Basin and more western areas. ${ }^{106}$ According to the author, based on written sources (annals of bamboo), Shang civilization began in $1523 \mathrm{BC}$ and In' ends in the $1300 \mathrm{BC}^{106}$ and the transition from Shang to Western Zhou took place in 1027 BC. Questions dating final stages of the existence of things north complex on the territory of modern China, especially the Late Bronze Age daggers and corresponding chemakyns and chariot equipment, discussed in detail by Dr. Jung Suk Bae: daggers with zoomorphic tops and curved handle type Chaodaogou he dates within the XIII-X cent $\mathrm{BC}$; daggers with a curved handle and pommel the second half of XII - the middle of the IX cent. BC; daggers with straight handle with grooves or without them the end of the X cent. until the VIII cent. BC (Nanshangen, Bayfu) and even later. ${ }^{6}$ Such dating may be similar to findings by its control of daggers in the Iranian Louristan and syncing.

\section{The iranian channel of communication}

Prof. E Grantovsky ${ }^{110}$ based on the analysis of some Iranian names of the rulers of Asia Minor and synchronous archaeological materials found that Protoiranians first began to appear in the territory of the Iranian plateau at the end of the II mill. BC and became plentiful here in the VIII cent. BC. In the culture of Iran in this period, a number of significant innovations in the monuments of fixed objects become known now as the Louristan Bronzes. Thus, in Hasanlu, Dink Tepe, Marlik, Babacan found alien ancient cultures of Iran rite ritual burial horses and in Louristan and Sialk VI ritual burial harness; bronze art in this period, notes the many images of people, riders, horses, griffins found in Amlashe and executed in the traditions and canons of the animal style. In Sialk VI and Gyan found the bronze bridle of Scythian type. ${ }^{17,111}$ Prof. R Ghirshman ${ }^{67,68}$ first compared these innovations in culture, tracked them Sialk, with the migration of the Indo-Iranians. This assumption is supported by the fact that these new features in the spiritual culture of Iran have a long tradition in the development of the Eurasian steppes. ${ }^{111-115}$ Apparently, the ritual burials and images of horses and riders record the path of the Iranian-speaking tribes to move to the Iranian plateau and brought with them skills of chariotry, horseridding, horse breeding and horse cult in general. Illustrative and key in this sense, we are the so-called Louristan Bronzes a collection of many different items, artfully poured out of high-quality metal with a high content of tin, made in an elegant art style, found mainly on the territory of the Iranian province of Louristan and presented today in expositions many of the largest museums in the world. Unfortunately, the vast majority of these remarkable objects are random finds, objects looting tombs, settlements, poorly documented, they themselves are not described in full and are not classified properly.

In the examples from the collection of Louristan Bronzes in the National Museum in Tehran and in the Archaeological Museum in the city of Hamadan ${ }^{12}$ of the Islamic Republic of Iran, with which the author was able to read, definitely divided into the following categories: anthropomorphic plastic items; parts of horse harness (bridle sets, some cheek-pieces and bells); jewelry (bracelets, pins, badges, earrings) and superior weapons a unique form of axes, daggers and arrowheads of Karasuk type. ${ }^{8,10,93}$ As part of this article briefly on only one category horse equipment and related communications features. Louristan bridle sets are solid bronze objects with onepiece rod mouthpiece, the edges of which there are cast bronze. Ends gnawed decorated in a twisted ring, which is attached to the ends of the reins. The design of such a kit is very painful for the horse in

${ }^{12}$ It is the same - the ancient Iranian city, the former capital of the Median Ecbatana in the Persian Empire, captured in 550 BC by Cyrus II the Great. operation since literally breaks the edge of the animal's mouth and repeats the action functional snaffle bridle type (using the cheek-piece (psalii) with spikes). According to experts, these early forms of the Middle East bridle sets could only be used in the chariot teams, which required a very strict remote control as opposed to riding a horse, because only they can ensure adequate and effective remote impact on the harness horses is in the management of fast chariot. ${ }^{116}$ This innovation could also be used for ill-trained, semi-wild horses from the herd, which only started to go around. It is likely that the first riding horses has become a well-trained and trained horses of the chariot rides pair. ${ }^{116,117}$

With the communicative point of view these bridle sets also noteworthy: highly artistic pictorial tradition in which they are made, very close to Central Asian figurative tradition in Zhetysu and Saryarka (Kazakhstan) $)^{118}$ and finds some similarities in synchronous Caucasian bronzes. ${ }^{119}$ Besides the general similarities in the iconography and repertoire, refers to the paired figures of animals: feline predators and horses, arranged vertically and feet together. These compositions were sealed and some bronze cheek-piece (psalii) considered bridle sets (one gnawed + are always a couple of cheek-pieces (psalii) in the form of figures of horses, wild rams, at least other animal species, but always pair) and other categories of objects of Louristan Bronzes (ornaments, plaques, tops of cults heads or special tops that were used to decorate the carriages) and petroglyphs on the rocks in Central Asia. ${ }^{93}$

Binary cheek-piece's motifs, their plots, species composition depicted animals and most importantly the manner of their implementation are very close to already established canons of the Scythian-Siberian (Saka) animal style ${ }^{13}$. Moreover, one of the cheekpiece in the form of figurines of horses, found during excavations of Ecbatana, the horse on his thigh, found tamga-shaped sign in the shape of a cross inscribed in a circle. This fact evidence of ancient and very important tradition of marking horses at the steppe, recorded by many sources, both written (Chronicles of Tanhuyyao, ancient Chinese, for example) and iconic (petroglyphs of Kulzhabasy, for example [120]. Customs entries in check-points in the north-western border of the Chinese empire firmly fixed on this tradition and more show the schedule of specific tamgas (signs of identity) genera steppe clans traditionally supplying trained horses in China. ${ }^{121}$

It is noteworthy that the tradition of branding horses are still preserved in Mongolia, Tuva, Khakassia, virtually all known nomadic peoples, the Kazakhs Zhuz among 31st varieties graphics of tamga members of the confederacy of tribes 13 tamgas (slightly less than half !) make different variations of the circle (the possible symbols of the sun, moon or wheel). ${ }^{122}$ Dr. Napil Bazylhan rightly so round tamgas connects with one of the most ancient Kazakh tribes Dulat (tou-lou in the Chinese annals) ${ }^{14}$ Curiously, the picturesque ruins of the capital of Cyrus the Great Pasargadae, her once majestic buildings and religious temples, now labeled tamgas as circles and petroglyphs, who confidently identified as the traditional Turkic petroglyphs Numerous Turkic tamgas plot drawings mountain goats, horsemen, archers, anthropomorphic characters, peculiar to Turk's petroglyph pictorial tradition, ${ }^{35}$ widespread in the northern regions of Central Asia Kazakhstan, Altai, East and West Turkestan. Obviously, these

${ }^{13}$ There is absolutely no images executed in early Arzhan-Mayemirsk style, dedicated to their time by Prof. Jacob A Sher ${ }^{123}$ on specific images of deer and their postures to "tips hooves" of Arzhan 1

${ }^{14}$ And it seems to us - this sign can be identified already mentioned in these pages clan tele-ti-dinlins 
petroglyphs were carved on the already ruined buildings of the city and left specific nomadic Turkic roots, as the fact of fixing stay here and ownership of these iconic for their land, directly related to their already distant forefathers, the memory of which are stored in the genetic component of this society in its code of self-identification. ${ }^{15}$

On no less significant role in the ancient Iranian society trained horses, horse riders and chariots evidenced by numerous written sources: the title of the ruler, indicating in a literal translation the control of horses and the names of the rulers of one of the etymologies: Tvishratha having a racing chariot, Abirattash Stand facing the chariots, Vriddhashva has great horses. ${ }^{124}$ The existence of a privileged class of soldiers (charioteers and/or riders) indicates the term Marianne, indicating to know from the Indo-Iranian Mar a man. ${ }^{111}$ In general, the situation on the Iranian plateau is consistent with the ideas expressed by Prof. Helena Kuzmina is localization and development of the Indo-Iranian (Aryan) ethnos including in Central and Southwest Asia, including the north of the Indian subcontinent (Andronovo), their progress from the Ural-Kazakhstan and South Russian, Ukrainian steppe (Srubnaya) in the south; ${ }^{111-113}$ It can be explained in the light of the theory of L. Gray and T. Barrow, the resettlement of Indo-Aryans and Protoiraniens. ${ }^{124,125}$ Indeed, identified channels of communication corresponds to the assumption of several waves of migrations of ancient Aryan (Indo-Iranians) and are reflected in the Avesta legends about the general ancestor of the Indo-Iranians Yam (Yima), which is three times expanding their land to the south, when it overflowed cattle, humans, dogs, birds and red lights glowing. In ancient Avesta texts described the central karshvar Hvanirata ${ }^{16}$ the country's of good chariots bounded by two mighty rivers Raha and Vahvi-Datya taking its origins in the world mountain Hara and the current in the Middle Sea Varukarta. On the whole territory of the country takes another 18 rivers. In another description of the ancestral home of the country's stated view Aryan-Vaydzha (Aryan space), where only river Vahvi Datya is the center of the Aryan world order Some scholars identify Raha rivers as the Volga and Vahvi-Datya to the Amu Darya. ${ }^{126}$

Written sources, mostly Vedic indicate Aryan ethnic heterogeneity: widespread tales of struggle devas (protoinduses) with his older brothers the asuras (protoiranians), the latter are divided into daityas and danavas descendants of river goddesses Diti and Danu. The Rigveda asuras mentioned as very real and specific enemies. Each of the ancient Iranian people there ethnogenetic own legend in which he was represented by a descendant of the hero-ancestor and spirit (is always in female form), the main river in the country of residence of the people. ${ }^{126}$ In addition, the Indo-Iranian sung and written sources are often referred to permanent and powerful enemies of Avestan Aryans mysterious tours. The names of their leaders do not like the Iranian or Indian and, apparently, these tribes are very different ethnic group,

${ }^{15}$ Thus, on these ruins was captured popular petroglyphs and especially in the Turkic time, the mems series - "I was here (my clan) favorite" content like other famous epigraphic monuments of Turkic inscriptions on ceramics, on the artifacts and on the rocks. Their meaning in the analysis of the tex messages, reduced to almost one statement (and fixing and the proclamation) ownership of the object, terrain, territory, pitcher, mirror and so on. According to verbal communication and amiable advice of Prof. Sergay Yatsenko, these petroglyphs and tamgas may be associated with many nomadic Turkic Qashqai tribe, settled in this area 300 years ago as a military settlers. However, we expect a more ancient age of these tamgas and petroglyphs. In any event, the detailed study of this phenomenon deserves a separate study and should be applied in other specific applications.

${ }^{16}$ It is possible, in a form transmitted name of the country of the Cimmerians - Gumirayya. but very close and related to the initial stage of the ethnogenesis of Indo-Aryan or Tocharian.

Obviously, such a heterogeneity of the Indo-Iranian ethnic group comes from the nature of the territorial settlement of these societies the gradual carting young members of the clan in search of new pastures, new ecological niches, in one - steppe landscape. The internal rules of the world order and self-sufficient and independent of the clan, its own mini-universe of its own world order within the boundaries of the clan, regulated by sociobiological factor the statussex. ${ }^{58,97,127}$ The interaction of parents with the local population, as well as migration of the youngest part of the clan, is constantly given new lines of development of this ethnic-clan (group of related clans) in the form of the formation of new technological skills in the material culture by means of their generation, or borrowing through their local women, the perception of other cultures customs and traditions of their own ethnic identity traits. All this led to a gradual transformation and sometimes complete assimilation and the dissolution of the local environment, primarily the parent lines of development, which, however, depended on the specific local conditions and the surrounding cultural environment. This is a feature of ethnogenesis nomads in the absence of well-defined area of formation of the ethnic group (or rather the complexities of the definition of such), the ancestral home of the mobile nature of any nomadic ethnic group. ${ }^{93}$

Thus, in the monuments Karasuk appearance and before Sakas time found plates with images of chariots (Arzhan 2, necropolis Hara Haia et al.) ${ }^{63,128,129}$ Karasuk petroglyphs on the rocks, ${ }^{100}$ details of chariot harness ${ }^{9,94,96}$ and a set of weapons of charioteers (in petroglyphs, deer stones and graves), other artifacts, ${ }^{93}$ the production of which is based on technology of socketed cast a unique bronze casting tradition. It seems that such a strong tradition figurative and metallurgical could occur in these areas under the influence of SeimaTurbino pulse, which apparently became the basis of formed later Karasuk and Tagar cultures. Graphic of Karasuk tradition manifested in numerous petroglyphs in Kazakhstan, Southern Siberia, Mongolia, China and Eurasian deer stones, as well as in the art of the Caucasus and Louristan bronzes.

Bright metallurgical tradition originally actively developing in the territory of Altai, Kazakhstan, East Turkestan and Inner Mongolia and then, as a result of interaction with the cultures of the Central Plains of China, the Iranian plateau, just expands its borders up to Eastern Europe and the Black Sea region. ${ }^{46-48}$ Perhaps this tradition of bronze casting, in combination with other advanced skills early developed a natural monopoly on the mass breeding and training horses for riding in chariots, became the basis of the power of Karasuk-Cimmerians and provided them with a significant advance far to the west of the continent. Traditionally, in the era of Early nomads riding horse and cavalry, as an effective new means of warfare, the communicator and how to clear a military innovation, coupled with the progressive forms of horse equipment ${ }^{17}$ and weapons ${ }^{18}$ allowed to make successful military campaigns in the territory of Western Asia, Near East and Eastern Europe become a formidable force in the context of geopolitical relations in all the Ancient East.

\footnotetext{
${ }^{17}$ This refers to the different types of horse bridle horse: semi-rigid - at Sakas and hard saddles, stirrups Turks.

${ }^{18}$ This refers to the specific types of bows and arrows and later with a long shaft of copies of the Sarmathians and Turks. Evolutionary this series is made in the complex weapons steppe knights - cataphractas (katafraktaries) - a symbiosis of a horse and rider, perfectly protected by a special armor of all types of offensive weapons.
} 
However, in developed countries of the Old World at the time, as in the West in Assiria, Persia, the Hittite kingdom in the ancient Greek polis and in the east in the ancient China, the army of their rulers were formed on the basis of mobile and well-trained units, consisting, in particular, of the large number of well-equipped with chariots, wagons baggage (supply vans) and yet very few groups of horse-riders. ${ }^{97}$ It is possible that to successfully resist such a huge and well-armed armies of Early nomadic tribes would have to use in their military units along with a well-trained and armed more riders and chariots. New findings on the territory of modern Kazakhstan and adjacent regions, allow to clarify this thesis. Among these amazing testimonies relate primarily wooden comb with a picture of the chariot and horse equipment some items from the burial of mound 6 in the Taksai I complex in the West Kazakhstan region, dated VI - the beginning of the V cent. BC. ${ }^{86}$, $93,130,131$ We can not say that the plot of chariots on the Taksay crest is only borrowed, or comb is made by the order in Persia, Assyria or Urartu. Features of technology of its execution, iconography, some of the details: the arcuate side of the body, physical type of characters and their position clearly indicate that the ridge is made, most likely by local craftsmen. In addition, there are direct analogies in the materials of Tasmola culture monuments and some burials of Arzhan I in Tuva, in southern Siberia, ${ }^{86,93}$ in Arzhan I, ${ }^{62,132}$ in the burial of mound 6 in the Taksay I ${ }^{86}$ in the necropolis Kyryk Oba ${ }^{133}$ and in Tuva and in the southern foothills of the Urals, it was found important evidence of the complex of Asian chariotry chariot obvious achievements of local technology. The presence in the grave of Taksay I the persian glass jugs, comb with chariots, plot and accidentally found next to a silver rhyton indicates active communication and cultural contacts with Assyria, Persia and other regions of the Near East during the time recorded in the written records of military campaigns of Cimmerians and then the Sakas of the Central Asia. These countries and their subsequent integration (disintegration) as part of the Achaemenid Empire. ${ }^{134-148}$

The tradition of building a two-horse chariots and wheeled carts appeared in the Bronze Age, was developed in Karasuk and Late Karasuk environment, as more likely to show an image of chariots on the walls of tombs in the petroglyphs on fences in Arzhan II, imitation burials with chariots in Arzhan I, picture chariots with Karasuk weapons and items chariot complex on deer stones. New findings of the Kazakh archaeologists confirm the active use of chariots in Sakas-Sarmathian communities. ${ }^{149-194}$ Opening in Pazyryk mounds of different types of vehicles trucks gigs, carts and four-wheel covered wagon executive type indicates the development of local traditions of their production, ${ }^{195}$ which embodies the underlying ideas of ancient Altai and skills, preserved by the times of their ancestors horsemen.

From a brief review of the development of vehicles in the Early nomads $^{35,196}$ the following assumptions about the use of a variety of types of wheeled vehicles and much more active than previously thought, the use of wheeled transport in their daily lives. This conclusion is evidenced by the data later written and pictorial sources of Turkic period. Known information about wagons loaded with treasures, at the headquarters of the Western Turkic Kagan Istemi, seen there Zemarh, envoy of the Byzantine emperor and in the "History of the Sui Dynasty" Referred to the nomadic Turkic tribes with a common name is already known to us the body, that "when moving used covered wagons with high wheels". ${ }^{197}$ It is with the ancestors of the Turkic-speaking tribes of the body and their alleged more distant relatives dinlins clearly identified with the carriers of Karasuk culture perhaps known in the Near Eastern literary tradition as the Cimmerians.

In general, as set out here understand the historical significance of
Seima-Turbino andronovo and Karasuk antiquities, as the dynamics of its development and in the relationships of carriers with other communities, based on communication which lay sociobiological factor status-sex, a common ethnic roots, the overall framework, to form the vast Ural-Altai-Kazakh, Minusinsk steppes within our earlier concept of the ancestral home of the nomadic Indo-Europeans. ${ }^{93}$ IndoAryan or Tocharian ethnic identity later became possible base formed later Karasuk (Cimmerian?) Ethnic group is inherently identification proto, somewhere on the steppes of Eastern Turkestan, Mongolia, Ordos (Gumirayi?) and the population carcass and Andronov communities and also, apparently, it was Tazabagyab culture and Indo-Iranian ethnic basis Scythian-Sakas tribes community. Perhaps it Karasuk tribes later became known in ancient Iranian sources as tours to the ancient Chinese as the tiekis - the (di) in Assyrian kvei or as a Cimmerian. Ancient Chinese written sources specify ethno-cultural situation in Central Asia and give reason to assume the existence of several large ethnic groups of rivems (possible ancestors wusuns and yuedzhy) and tyres (di) tieks dinlins - (possible karasukians) on the northern and western borders of the Central Plains China.

Attempts to find the remains of material culture tours-tiCimmerian-karasukians in the territories of the ancient Near East ${ }^{17}$ submitted in advance doomed to failure because they were mobile raids, hiking exclusively for prey, "lightning" on the historical scale; probably fallen soldiers according to the prevailing burial traditions were burned and in memory of their heroic deeds at home in Gumiraye, unique cenotaphs erected many memorial complexes with deer stones and without them. ${ }^{99}$ Considered period in the history of the population of Eurasian steppe communications demonstrate the formation of loops and channels of communication livestock on the basis of new inventions, which brought to the forefront of world history, as opposed to the soldier-charioteer, horseman warrior on horseback. ${ }^{85,105,198,199}$ Development of communications at this time leads to important historical events the development of new routes of the Silk Road, to the Great Migration return migration from east to west on the ancestral home of his distant ancestor, had become semimythical and revered heroes of verbal and visual art, the characters of the heroic epic, mythological stories and legends. ${ }^{200-223}$

\section{Acknowledgements}

None.

\section{Conflict of interest}

Author declares that there is no conflict of interest.

\section{References}

1. Akishev KA. Sakas Asian and European Scythians. Archaeological research in Kazakhstan. Nauka, Kazakhstan; 1973. p. 43-58.

2. Massanov NE. Kazakh nomadic civilization: the basics of life migratory habits of society. Almaty Print S: Russia; 2011. p. 740.

3. Akishev KA. Kurgan Issyk Art of Sakas of Kazakhstan. M Art, Kazakhstan. 1978. p. 132.

4. Hasanov Z. Read of the Issyk inscriptions, Cultural Dialogue Eurasia in Kazakhstan archeology. Coll research papers dedicated to the 90th anniversary of the prominent archaeologist $K$ Akishev. Kazakhstan; 2014. p. 215-230.

5. Kovalev AA. The origin of the Scythians according to archaeology. In: Kushnareva KH, Lazarus N, editors. Between Asia and Europe Caucasus in IV-I mill BC. Proceedings of the conference dedicated to the 100th birth anniversary of AA Jessen. SPb Publishing House of the State Hermitage: USA; 1996. p. 121-127. 
6. Kovalev AA. Earliest dated monuments of Scythian art (type Nanshangen). In: Samba IU, Reshetov AM, editors. The ancient cultures of Central Asia and St. Petersburg. Proceedings of the scientific conference dedicated to the 70th anniversary of the birth of AD Grach $\mathrm{SPb}$ Cult Inform Press, 1998. p. 122-131.

7. Chlenova NL. The origin and early history of the tribes of Tagar culture. Kazakhstan: M Nauka; 1967.

8. Chlenova NL. Karasuk daggers. Kazakhstan: M Nauka; 1976.

9. Novgorodova EA. Central Asia and the Karasuk problem. Russia: M Nauka; 1970. p. 176

10. Novgorodova EA. Ancient Mongolia. Russia: M Nauka; 1989. p. 384

11. Terenozhkin AI. Cimmerians. Naukova Dumka, Ukraine; 1976.

12. Chugunov KV. Synchronization of early Scythian time cultures of Central Asia, South Siberia and Kazakhstan. In: Derevianko AP, Molodin VI, editors. Current problems of Russian archeology. Proceedings of the Archaeological Congress T2, Institute of Archaeology and Ethnography of SB RAS. Russia; 2006. p. 69-71.

13. Novozhenov VA. Earliest smiths of Eurasian steppe (Karasuk culture and the origin of the phenomenon of Begazy-Dandybay). Begazy-Dandybay culture of the Eurasian Steppe, Collection of articles dedicated to the 65th anniversary of J Kurmankulov, Kazakhstan, 2013a. p. 321-329.

14. Murzin VY. Cimmerian problem in the European and Asian contexts. In: Beisenov AZ, editor. Begazy Dandybay culture of steppe Eurasia Coll articles. Russia; 2013. p. 137-149.

15. Dandamaev MA. Mesopotamia and Iran in the VII-IV centuries BC: ideolgy and social institutions. St Petersburg State University, Russia; 2009. p. 512 .

16. Dandamaev MA. Babylonia in the 626-330 BC: the social structure and ethnic relations. Linguistic Society. Russia; 2010. p. 222.

17. Ivanchik AI. Cimmerians and Scythians. Cultural and historical and chronological problems of archeology of Eastern European steppes and the Caucasus pre and early Scythian time. Steppe peoples of Eurasia Paleography. 2001. p. 324

18. Shahbazi S. The authorative guide English edition. Safiran Publishing, Iran; 2013.

19. Dyakonov IM. History of Media. Nestor History. 2008. p. 526.

20. M Nauka. Kobylina M Miletus. Russia; 1965. p. 124.

21. Khodzhaev A. From the history of the ancient Turks. Publishing House of Academy of Sciences of Uzbekistan, Uzbekistan; 2010. p. 238

22. Commissarov SA. Complex weapons of ancient China. Late Bronze Age, Novosibirsk. Russia; 1988. p. 178.

23. Kovalev AA. Localization peoples of VI-III cent. BC on the northern borders of the Chinese State (according to archaeological and written sources). Notes of the Institute of History of Material Culture RAS No. 3, Russia; 2008. p. 181-202.

24. Kovalev AA. New data on the connection between culture of Western Siberia, Mongolia and China in the first half of the II millennium. BC. In: Tishkin A, editor. Modern solution of urgent problems of Eurasian archeology. Altai University, Russia; 2013. p. 140-146.

25. Kovalev AA, Erdenbaatar D. Late Bronze Age and the beginning of the early Iron Age in Mongolia in light of the findings of the Internationa Central Asian archaeological expedition. Ancient cultures of Mongolia and Baikal in Siberia, Proceedings of the international scientific conference. Buryat University Publishing House, Russia; 2010. p. 104-117.

26. Linduff KM. Zhukaigou: Steppe Culture and the Rise of Chineese Civilization. Antiquity. 1995;69(262):132-147.
27. Linduff KM. Beyond the Steppe and the Sown. In: Lindaff KM, editor. Proceedings of the 2002 University of Chicago Conference on Eurasian Archaeology. Chicago Univ Press, USA; 2006. p. 358-370.

28. Linduff KM. Trade and exchange of goods in the end of I mill. BC after investigations of MP Gryaznov. Eurasian steppe cultures and their interaction with the ancient civilizations, Proceedings of the international scientific conference dedicated to the 110th anniversary of the birth of the outstanding Russian archaeologist MP Gryaznov T2. Publishing House IHMC, Russia; 2012. p. 412-420.

29. Linduff KM. Why Siberian artifacts found within the boundaries of the Chinese state? Nomadic Indo-European homeland, The Island of Crimea, Russia; 2014. p. 300-307.

30. Klein LS. Tochars migration in the light of archeology. Stratum plus. 2000;2:178-187.

31. Klein LS. Origin of the Indo-Europeans and archeology. In: Alëkshin VA Bobrovskaya EV, editors. Eurasian steppe cultures and their interaction with the ancient civilizations. Proceedings of the international scientific conference dedicated to the 110th anniversary of the birth of the outstanding Russian archaeologist MP Gryaznov. Publishing House IHMC, Russia; 2012. p. 25-34.

32. Kiselyov SV. Ancient history of Southern Siberia. Russia: M Nauka; 1949. p. 364

33. Suleymanov BC. On the question of the ethnic attribution of certain archaeological cultures of the Bronze Age in the North of Central Asia. In: Baytanaev BA, editor. Archaeology in the era of independence of Kazakhstan: results and prospects, Proceedings of the international scientific conference devoted to 20 anniversary of Independence of Kazakhstan and the 20th anniversary of the Institute of Archaeology. Almaty Institute of Archaeology, Kazakhstan; 2011. p. 404-407.

34. Taşağıl A, Gök Türkler. Türk Tarih Kurumu Basimevi. Türk Tarih Kurumu. Turkey; 2004.

35. ZTKA. Western Turk Qaganat. Nazarbayev Center. Kazakhstan; 2013. p. 884 .

36. Piotrovsky BB. Kingdom of Van. Russia: M Nauka; 1959.

37. Dyakonov IM. History of Media from the ancient times to the end of the IV BC. ML Eastern Literature. 1956. p. 485.

38. Jessen A. To a question about the monuments of VIII-VII cent, BC in the south of the European part of the USSR, Russia; 1953. p. 49-110.

39. Terenozhkin AI. Monuments of Scythian time in Ukraine. KSIIMK. $1952 ; 47: 3-14$

40. Neukhardt AA.Herodotus Scythian in the national historiography. Russia: L Nauka; 1982

41. Ehrlich VR. In defense of the tradition of Black Sea origin of Cimmerian. 1994. p. 168-175.

42. Makhortykh SV. Cimmerians of the Northern Black Sea. Ukraine; 2005 p. 324.

43. Ehrlich VR. Northwest Caucasus in the Early Iron Age: protomeot group of monuments. Russia: M Nauka; 2007. p. 344.

44. Safronov VA. Indo-European homeland. Volga-Vyatka Publishing House, Russia; 1989. p. 396.

45. Gamkrelidze T, Ivanov VV. Indo-Europeans and Indo-European language. Parts 1-2. Tbilisi University, Georgia; 1984. p. 1328.

46. Chernukh EN. Steppe belt of Eurasia: The Phenomenon of nomadic cultures. Handwritten monuments of ancient Russia. Russia; 2009. p. 624

47. Grigoriev SA. Metallurgical industry in Northern Eurasia during the Bronze Age. Russia: Cicero; 2013. p. 622. 
48. Minasyan RS. Metal in antiquity and the Middle Ages. StPb State Hermitage. Russia; 2014. p. 422.

49. Cugunov K, Parzinger H, Nagler A. Der skythen zeitliche Fursten kurgan Aržan 2 in Tuva. Philipp von Zabern. Germany; 2010. p. 330

50. Chlenova NL. On the connections of the Northwest Black Sea and Lower Danube to the east in the Cimmerian era. Studia Thracica I. 1925. p. 69-80.

51. Murzin VY. Origin of Scythians: basic stages of formation of the Scythian ethnos. Naukova Dumka. Ukraine; 1990. p. 234.

52. Kovalev AA. The origin of deer stones of the western region. In: Olkhovskii B, editor. Archaeology, paleoecology and paleodemography of Eurasia. M Geos; 2000. p. 138-180.

53. Kovalev AA. On the origin of culture of Deer stones. In: Froyanov IY, Astakhov SN, editors. Eurasia through the centuries. Publishing House of St. Petersburg University and the IHMC, Russia; 2001. p. 160-166.

54. Volkov VV. Deer stones of Mongolia. M Scientific World. UK; 2002. p. 248.

55. Chugunov KV. Cultural ties of Tyva population in early Scythian time. In: Habdulina MK, editors. Margulan read, Kazakhstan; 2011. p. 177-182.

56. Chugunov KV. Synchronization of archaeological cultures of Early Sakas time in Kazakhstan and Tyva. In: Beisenov AZ, Lohman VG, editors. Saka culture of Saryarka in the context of the study of the ethnocultural processes of Eurasian steppe. Karaganda University, Kazakhstan; 2011. p. 69-77.

57. Gryaznov MP. Arzhan: Royal mound of Early Scythian time. Russian: L Nauka; 1980. p. 232

58. Novozhenov VA. Rock carvings of carts from Middle and Central Asia (to the problem of migration in the Eurasian steppe Eneolithic and Bronze). Arguments and Facts. Kazakhstan; 1994. p. 297.

59. Epimakhov AV. Horizon of chariot cultures Bronze Age: evaluation of heuristic capabilities. Proceedings of the Chelyabinsk Scientific Center. 2008;1(39):93-96.

60. Lazaretov IP. Monuments of the Late Bronze Age of Khakass-Minusinsk depression: Chronology, periodization, the terms. Begazy-Dandybay culture Eurasian Steppe. Collection of articles dedicated to the 65th anniversary of J Kurmankulova. - Kazakhstan; 2013. p. 371-400.

61. Polyakov AV. Early stages of the Late Bronze Age in the Middle Yenisei. In: Beisenov AZ, editor. Begazy-Dandybay culture of Eurasian Steppe. Collection of articles dedicated to the 65 - anniversary of J Kurmankulov, Kazakhstan; 2013. p. 401-417.

62. Savinov DG. Early nomads of Upper Yenisei. Archaeological Culture and cultural genesis. St. Petersburg State University, Russia; 2002. p. 258.

63. Chugunov KV. Plates with petroglyphs in the complex Arzhan 2 (a chronology of Arzhan-Maiemir style). Sovetova OS, Miklashevich EA, editors. Path millennia Coll scientific papers on the anniversary of MA Devlet. Kemerovo State University, Russia; 2008. p. 53-69.

64. Gryaznov MP. Chariot of Early nomads of Altai. 1955. p. 30-32.

65. Vadetskaya EB. Archaeological sites in the steppes of the Middle Yenisei Russia: L Nauka; 1986. p. 127.

66. Gryaznov MP. Milestones pastoral tribes of Kazakhstan and Southern Siberia in the Bronze Age. Xiao 26. 1957. p. 21-28.

67. Ghirshman R. L'Iran et la migration des indo-aryens et des iranyens. Netherlands: E Brill; 1977. p. 88

68. Ghirshman R. Tombe princiere de Ziwiye et la debut de l'art animalier scythe. CNRS; France; 1979. p. 51.
69. Muscarella OW. Ziwiye and Ziwiye: the Forgery of a Provenience. Journal of Field Archaeology. 1977;4(2):197-219.

70. Vasilev LS. Agrarian relations and the community in ancient China (XIVII centuries BC). M Nauka. Russia; 1961. p. 320.

71. Vasilev LS. Problem of the genesis of Chinese civilization: the formation of the material foundations of culture and ethnicity. Russia: M Nauka; 1976. p. 368.

72. Chechushkov IV, Epimakhov AV. Chariot and harness as a cultura indicator of the evolution of horse breeding. In: Kuznetsov PF, editor. Chariot complex of Ural-Kazakhstan steppes, The horses, chariots and charioteers Eurasian steppes, Institute of Plant and Animal Ecology UO RAS, Kazakhstan; 2010. p. 182-229.

73. Samashev Z. Petroglyphs of Kazakhstan as a historical source. Hist Sciences. Kazakhstan; 2010. p. 56.

74. Bobomulloev C. Excavations of burial structure Zardchahalifa Proceedings of the Academy of Sciences of the Republic of Tajikistan. Series of Oriental history, philology. Acad Tajikistan, Tajikistan; 1993. p. $56-63$.

75. Epimakhov AV, Dynamics of Communications. Urals Bronze Age nomadic Indo-European homeland. The Island of Crimea, Kazakhstan 2014. p. 125-205.

76. Chernykh EN, Kuzmin SV. Ancient Metallurgy of Northern Eurasia. Nauka. Kazakhstan; 1989. p. 320.

77. Loehr M. Chinese Bronze Age Weapons. Oxford Univ Press, USA; 1956.

78. Zdanowicz GB. Bronze Age of Ural-Kazakhstan steppes. Ural university, Russia; 1988. p. 184

79. Gening VF, Zdanowicz GB, Gening VV. Sintashta: Archaeological site of the Aryan tribes of the Ural-Kazakhstan steppes. South Ural Publishing House, Russia; 1992. p. 407.

80. Bochkarev VS. On the question of the chronological relationship Seima and Turbino cemeteries. Problems of archeology of Dnieper. 1986;3:106-108.

81. Kadyrbaev MK, Kurmankulov J. Culture of ancient herdsmen and metallurgists of Sary-Arka. Almaty Gylym. 1992. p. 247.

82. Kukushkin IA. Hardware of the Early Andronovo's burial Ashchisu. Russia; 2011. p. 110-116.

83. Khudyakov YS. Khereksury and deer stones: Archaeology, Ethnology and Anthropology of Mongolia. Nauka. Russia; 1987. p. 136-162.

84. Khudyakov YS. Military ancient nomads of South Siberia and Central Asia. Novosibirsk, Novosibirsk State University, Russia; 1995. p. 138.

85. Khudyakov YS. Features of formation of weapons systems of the ancient nomads of the Sayano-Altai in the early Scythian period. Cultural Dialogue Eurasia in Kazakhstan archeology, Collection of articles dedicated to the 90 year anniversary of the outstanding archaeologist $K$ Akishev. Kazakhstan; 2014. p. 704-714.

86. Altynbekov K. Rejuvenated treasures of Kazakhstan: the experience of scientific restoration. Almaty, The Island of Crimea, Kazakhstan; 2014 p. 364 .

87. Solovyov AI. Weapons and Armor Siberian weapons from the Stone Age to the Middle Ages. INFOLIO Press, Russia; 2003. p. 234.

88. Dobzhansky VN. Dialers belt nomads of Asia. Novosibirsk State University, Russia; 1990. p. 163.

89. Ermolenko LN. Fine monuments and epic tradition: based on the culture of ancient and medieval nomads of Eurasia. Tomsk State University, Russia; 2008. p. 278. 
90. Shulga PI. Horse riding equipment and military zones in the Altai. Part Early Scythian time, Publishing House of Altai University, Russia; 2008. p. 348

91. Varenov AV. On the functional purpose of «model yoke» of Yin and Zhou period. New in archeology of China, Research and problems, Nauka. Russia; 1984. p. 42-52.

92. Varenov AV. Dating of weapons shown in deer stones of Mongolia Military and medieval archeology of Central Asia, Publishing House of the Kemerovo University, Russia; 1995. p. 231-239.

93. Novozhenov VA. Great Steppe and Man in the Ancient Communications Network. In: Epimakhov AV, editor. Ethnic history of ancient nomads of the steppes of Eurasia/Collective monograph in memory of EE Kuzmina, Kazakhstan; 2014. p. 18-267.

94. Hsiao W. The role of the transmission of chariots in the early east-west interaction: 2000 - 1200 BCE. The National Palace Museum research quarterly. 2011;28(4):119-132.

95. Hsiao W. Study on chariot burials in Early China, 1200-210 BCE. Aurora Center for the Study of Ancient Civilization. Peking University Publication Series: 2009;20:257.

96. Hsiao W. Chariots in Early China: Origins, cultural interaction and identity. Oxford Archaeopress. 2013;26(3):534-535.

97. Novozhenov VA. Communication and the Earliest Wheeled Transport of Ancient Eurasia. M Taus. Russia; 2012. p. 498.

98. Kovalev AA, Erdenbaatar D. Tradition of using of deer stones of Mongolia. In: Tishkin A, editor. Stone sculpture and small plastic ancient and medieval peoples of Eurasia. Publishing House of Altai University, Russia; 2007. p. 99-105.

99. Kovalev AA, Rukavishnikova IV, Erdenbaatar D. Deer stones are monuments cenotaphs (based on the latest research in Mongolia and Tuva). Ancient and medieval sculptures of Central Asia. Altai University, Russia; 2014. p. 41-54.

100. Kovaleva OV. Rock paintings of the Late Bronze Age in the Minusinsk Basin. Institute of Archaeology and Ethnography. Russia; 2011. p. 160.

101. Chen TK. The Origin and Development of Shang Culture. Asia Major 1957;6:80-98.

102. Chen TK. Metallurgy in Shang China. Toung Pao. 1974;60:209-229.

103. Kucera S. Chinese archeology 1965-1974: Paleolithic the era of Yin. Findings and challenges. M Nauka. Russia; 1977. p. 234.

104. Kozhin PM. About chronology of monuments in Anyang. In: Larichev V, editor. In the era of ancient China, Russia; 1990. p. 45-56.

105. Kozhin PM. China and Central Asia before the Chinghis Khan: paleoculturological problems. M Publishing House Forum, Russia; 2011. p. 368 .

106. Lin Yun. Revaluation of the relationship between the bronze wares Shan culture and the northern zone. China in the era of antiquity. Nauka. Russia; 1990. p. 29-45.

107. Epimakhov A, Hanks B, Renfrew K. Radiocarbon chronology of the Bronze Age monuments of Sout Ural. 2005. p. 110-127.

108. Chechushkov IV. Chariot's set of the Late Bronze Age steppe and forest steppe of Eurasia. East Sciences RAS. Russia; 2013. p. 29

109. Chechushkov IV. Distribution of wheeled transport in the light of the radiocarbon chronology. In: Epimakhov A, editor. Sacrament of the ethnic history of the ancient nomads of the steppes of Eurasia. Almaty. Kazakhstan; 2014. p. 274-285.

110. Grantovsky EA. Early history of the Iranian tribes of Asia Minor, 2nd ed. M Nauka. Russia; 1970. p. 396.
111. Kuzmina EE. Whence came the Indo-Aryans? The material culture of the tribes of Andronov community and origin of Indo-Iranians. Russian Institute for Cultural Academy of Sciences and RF Ministry of Culture. Russia; 1994. p. 464

112. Kuzmina EE. Aria way to south. M StPb, KomKniga. Russia; 2008. p 360 .

113. Kuzmina EE. Classification and periodization of monuments of Andronovo cultural community. Aktobe Print A. Russia; 2008a. p. 324.

114. Pogrebova MN. History of Eastern Transcaucasia (in the first half of the second - the beginning of the first mill. BC). Institute of Oriental Studies. Russia; 2011. p. 344.

115. Mallory JP. Indo-Europeans. Language, Archaeology and Myth. Thames \& Hudson, UK; 1989. p. 186-199.

116. Littauer MA, Crouwel JH. Wheeled vehicles and ridden animals in the Ancient Near East. EJ Brill. Netherlands; 1979. p. 185.

117. Weinstein SI. World of nomads in the Centre of Asia. M Nauka. Russia; 1991. p. 296.

118. Dzhumabekova GS, Bazarbaeva GA. Artistic bronzes of Zhetysu. Almaty. Kazakhstan; 2013. p. 278.

119. Brileva OA. Ancient bronze anthropomorphic plastic from Caucasus (XV century BC - X century AD.). Gos Museum of Oriental Art M, Taus. 2012. p. 320.

120. Rogozhinsky AE. Tamgas in the petroglyphs of medieval nomads of Kazakhstan: results of the latest research and prospects of further study. Coll. International scientific and practical seminar "Historical and cultural heritage and contemporary culture.» Service Press, Kazakhstan; 2012. p. 91-104

121. Zuev YA. Tamgas of horses from vassal states (translated from Chinese writings 8-10 centuries. Tanhuyyao, Vol. 3, juan 72, pp. 1305-1308). Proceedings of the Institute of History, Archeology and Ethnography of the Kazakh SSR. 1960;8:87-96.

122. Bazylhan N. Some historical-source study problems associated with the traditional system of tamgamaking practice of Kazakhs. Proceedings of the international scientific-practical seminar "Historical and cultural heritage and contemporary culture. Service Press, Kazakhstan; 2012. p. 84-90.

123. Sher YA. Early stage of Scythian art. Scythian-Siberian cultural and historical unity. Kemerovo University, Russia; 1980. p. 344-346.

124. Burrow T. The Proto-Indoaryans. JRAS. 1973;2:122-149.

125. Litvinsky BA. Copper pots from Hindustan and Pamir. Archaeology, paleoecology and paleodemography of Eurasia. M Geos. Russia; 2000. p. $277-294$.

126. P'yankov IV. Some questions of ethnic history of ancient Central Asia. East Orient. 1995;6:3-27.

127. Novozhenov I. Status-sex and Evolution of Man. Ural University, Russia; 1991. p. 132.

128. Filippova EE. Burial with chariot of Karasuk time. In: Devlet MA, editor. The study of rock art in the Soviet Union, M Nauka. Russia; 1990. p. $166-168$.

129. Filippova EE. Funeral petroglyphs of Middle Yenisei and their place in the ideological views of Karasuk tribes. Archaeological Collection The funeral rite, Proceedings of the State Historical Museum. 1997;93:62-69.

130. Sdykov MN, Lukpanova YA. Early Nomads of Western Kazakhstan (a complex of Taksay I). Poligrafservis. Russia; 2013. p. 292.

131. Lukpanova YA. The suit of woman in the Sarmatian era: experience of reconstruction. Cultural Dialogue Eurasia in Kazakhstan archeology, Collection of articles dedicated to the 90th anniversary of the prominent archaeologist K Akishev. Saryarka. Kazakhstan; 2014. p. 430-440. 
132. Smirnov NY. What went «king» of Arzhan?. In: Aliokshin VA, et al., editors. Eurasian steppe cultures and their interaction with the ancient civilizations, Proceedings of the international scientific conference dedicated to the 110th anniversary of the birth of the outstanding Russian archaeologist MP Gryaznov, IHMC, Russia, 2012. p. 424-431.

133. Bisembayev AA, Gutsalov SY, Sdykov MN. Research of burial mounds complex Kyryk Oba. Report on archaeological research under the State program «Cultural Heritage» in 2005. Almaty. Archaeological institute, Kazakhstan; 2006. p. 231-235.

134. Agapov P, Kadyrbaev MK. Treasures of Ancient Kazakhstan. Kazakhstan; 1979. p. 242.

135. Akishev KA. Ancient and medieval States on the territory of Kazakhstan. Institute of Archaeology, Kazakhstan; 2013.

136. Akishev KA, Akishev AK. Problem of chronology of the early stage of culture of Saka. Archaeological sites of Kazakhstan. Kazakhstan; 1978. p. $38-63$.

137. Akishev AK. Art and mythology of Sakas. Nauka. Kazakhstan; 1984. p. 158.

138. Altynbekov K. Reborn from the ashes. Reconstruction of burial materials priestess of a complex of Taksay I. The Island of Crimea, Kazakhstan 2013. p. 64

139. Altynbekov K, Novozhenov VA. Upgrade Andronov chariots. Reborn treasures of Kazakhstan: the experience of scientific restoration. Almaty. Kazakhstan; 2014. p. 256-273.

140. Altynbekov K, Novozhenov VA. Carts of the Early nomads in the heart of Eurasia. Nomadic Indo-European homeland. Collective monograph memory of EE Kuzmina, Almaty. Kazakhstan; 2014a. p. 308-344.

141. Beisenov AZ. Saryarka steppe cradle of civilization. Almaty. 2011;32.

142. Childe VG. The Diffusion of Wheeled Vehicles. Ethnographisch archaeologische Forschungen. 1954;2:1-17.

143. Chlenova NL. Chronology of monuments of Karasuk era. M Nauka. Kazakhstan; 1972.

144. Chlenova NL. About the time of the Iranian-speaking population in the Northern Black Sea. Ethnogenesis peoples of the Balkans and Northern Black Sea. M Nauka. 1954. p. 259-268.

145. Chlenova NL. Deer stones as a historical source. Novosibirsk, Nauka, Kazakhstan; 1984a.

146. Chlenova NL. On the issue of Central Asian origin of the Scythians hypothesis: Date of Deer stones of Mongolia. Antiquity: the historical significance and the specific source. Abstracts of the conference, dedicated to the memory of E.A. Grantovsky M. 1996. p. 125-127.

147. Chlenova NL. Central Asia and the Scythians. Date of Arzhan and its place in the culture of the Scythian world. M IA RAS, Russia; 1997.

148. Chung SB. On the chronology of complexes with the Late Bronze Age daggers of the North China. Olshansky VS, editor. Archaeology, palaeoecology and paleodemoasgraphy of Eurasia Coll articles. M Geos. USA; 2000. p. 110-137.

149. Commissarov SA. Zhou chariots. Proceedings of the Academy of Sciences of the USSR. 1980;1(1):156-163.

150. Curtis JE. Ancient Persia. British Museum Press, UK; 2011. p. 96.

151. Curtis JE, Reade JE. Art and Empire: Treasures from Assyria in the British Museum. British Museum Press-Harry N Abrams. UK; 2000. p. 224 .

152. Ehrlich VR. At the root of the early Scythian complex. M Nauka. Russia; 1994a. p. 198
153. Epimakhov AV. Early complex societies of the north Central Asia (based on burial Stone Barn 5). Part 1-2, Russia; 2005;p:192.

154. Epimakhov AV. Estimating evidence of distant relations in the era of paleometal. Vestnik Chelyabinsk State University 2012;34(288):5-9.

155. Evdokimov VV. Bronze Age steppes of Central and Northern Kazakhstan. East Sciences. Kazakhstan; 2001. p. 32.

156. Evdokimov VV, Varfolomeev VV. Bronze Age of Central and Northern Kazakhstan. Karaganda Publishing House of the University, Kazakhstan; 2002. p. 138.

157. Gay AN. Novotitorovka culture. Old Garden. 2000. p. 224.

158. Gryaznov MP. Pazyryk mound. Nauka. Russia; 1937.

159. Gryaznov MP. First Pazyryk mound. M Nauka. Russia; 1950.

160. Gryaznov MP. Some questions of history and the addition of Early nomadic societies of Kazakhstan and Southern Siberia. 1955. p. 19-29.

161. Gook DK, Nikolaev NN. Wagon of the Fifth Pazyryk mound. In: Aliokshin VA, Bobrovskaya EV, editors. Eurasian steppe cultures and their interaction with the ancient civilizations. Proceedings of the international scientific conference dedicated to the 110th anniversary of the birth of the outstanding Russian archaeologist MP Gryaznov T2$\mathrm{StPb}$, Publishing House IHMC, 2012. p. 454-457.

162. Tepfer JE. The Image of the Wheeled Vehicles in the Mongolian Altai: Instability and Ambiguty. The Silk Road. 2012;10:1-28.

163. Seogho J, Mongolian ED. Altain khadny zurag. Inst of Archaeology Mong Acad of Scienses. Mongolia; 2008.

164. Seogho J, Mongolian ED. Mongolyn baruun khoid aimgiin khadny zyrag. Inst of Archaeology Mong Acad of Scienses, Mongolia; 2009.

165. Izbitser EV. Burials with carts from steppe zone of Eastern Europe and the North Caucasus. Dis kand hist IHMC. 1993. p. 28.

166. Historical Records by Sima Qian. Eastern Literature. 1972.

167. Kadyrbaev MK. Tasmola Cultural Monuments. In: Margulan AH, et al. editor. Ancient culture of Central Kazakhstan. Alma Ata: Science Gylym, Kazakhstan; 1966. p. 303-428.

168. China: history and civilization. Xinhua. China; 2007. p. 288.

169. Kovalevskaya VB. Assyrian chariots of IX-VII cent. BC: the development over time based on the analysis of statistical data. In: Karganova G, editor. Institute of Oriental Studies. Russia; 2013. p. 73-81.

170. Kozhanov ST. Wheel Transportation of Han period. New in archeology of China: Research and concerns, Russia; 1984. p. 67-75.

171. Korolkova EF. Rulers of the steppes. StPb The State Hermitage. Russia; 2006. p. 136

172. Kuzmina EE. Prehistory of the Silk Road: cultural dialogue between Europe and Asia. KomKniga. Russia; 2010. p. 124.

173. Kurochkin GN. Scythian roots of Siberian shamanism: a new attempt to «read» Pazyryk mounds. Surfactants,. Russia; 1994. p. 60-70.

174. Kucera S. Occurrence of metallurgy in ancient China. Antiquities. Egypt; 2000. p. 27-39.

175. Legrand S. Karasuk Metallurgy: Technological Development and Regional Influence. In: Linduff KM, editor. Metallurgy in Ancient Eurasia from the Urals to the Yellow River. Edwin Mellen Press, USA; 2004. p. 340-357.

176. Legrand S. The emergence of the Scythians: Bronze Age to Iron Age in southern Siberia. Antiquity. 2006;80(310):843-879. 
177. Legrand S. Sorting Out Men and Women in the Karasuk Culture. In: Linduff KM, Rubinson KS, editors. Are All Warriors Male Lanham. Spain; 2008. p. 153-174.

178. Linduff KM. Art and Identity: The Chinese and Their "Significan Others" in the Shang. In: Gervers M, Schlepp, editors. Cultural Contact, History and Ethnicity in Inner Asia: Papers presented at the Central and Inner Asian Seminar, Toronto Univ Press, USA; 1994. p. 12-48.

179. Linduff KM A. Walk on the Wild Side: Horses and Horse Gear in Shang China. In: Renfrew C, editor. Late Prehistoric Exploitation of the Eurasian Steppe. Cambridge Univ Press, USA; 2002.

180. Linduff K. Mettalurgy in Ancient Eastern Eurasia from the Urals to the Yellow River. Chainese Studies. 2004;31:231-297.

181. Liancheng L. Chariot and Horse Burials in Ancient China. Antiquity.1993;67(257):824-838

182. Macqueen JG. The Hittites. In: Thames, Hudson, editors. UK; 2010. p. 176.

183. Margulan AH. Begazy Dandybay culture of Central Kazakhstan. Alma Ata, Nauka. Russia; 1979. p. 320.

184. Marsadolov LS, Tishkin AA. Basic bibliography of printed works of archaeologists over the past 50 years (1947-1997) Saddlery of I mill. BC in the steppe zone of Eurasia. In: Kiriushin YF, Tishkin A, editors. Outfit riding horse in the Altai region in the early Iron Age and the Middle Ages. Collection of scientific papers. Altai University, Russia; 1998. p. 91-92.

185. Maspero G. History of Egypt, Chaldcea, Syria, Babylonia and Assyria. The Grolier society publishers. UK; 1916. p. 456.

186. Masson VM. Culturogenez of Ancient Central Asia StPb IHMC, Russia; 2006.

187. Miller B. Vehicles of the Steppe Elite: Chariots and Carts in Xiongnu Tombs. The Silk Road. 2012;10:29-38.

188. Muhareva AN. Covered wagons Images of rock art in Central Asia Archeology of Southern Siberia, Publishing House of the Kemerovo University, Russia; 2011. p. 72-78.

189. Nefiodkin AK. Chariots and charioteers of ancient Greeks (XVI-I centuries. BC). StPb Oriental. 2001. p. 528.

190. Novgorodova EA. World of petroglyphs of Mongolia. M Nauka. Russia; 1984. p. 168.

191. Novozhenov VA. The Composition with a Chariot in the Bronze Age Petroglyphs of Mongolia. International Newsletter on Rock Art. 1993;6:7-10.

192. Novozhenov VA. Asian chariots (to the problem of the Asian chariot complex). In: Baytanaev BA, editor. Archaeology in the era of independence, Kazakhstan: results and prospects, Proceedings of the international scientific conference devoted to 20 - anniversary of Independence of Kazakhstan and 20, Institute of Archaeology. Kazakhstan; 2011. p. 247-256.

193. Novozhenov VA. Andronovo pictorial tradition: the end of a myth? (methodological aspect). In: Lohman VG, editor. Archaeology and History of Sary Arka. Kazakhstan; 2012a. p. 114-145.

194. Novozhenov VA. A Carts of the Early Nomads in the Central Asia. In: Kalshabaeva BK, editor. Proceedings of the international scientificpractical conference «Actual problems and prospects of development of archeological and ethnological science in Kazakhstan», dedicated to the 80th anniversary of the KNU Al-Farabi and the 90th anniversary of honorary academician of NAS RK W.C. Shalekenov, Kazak university, Kazakhstan; 2014a. p. 142-151.

195. Samashev Z. The ancient art. Kazakhstan, 2013. p. 240.
196. Zuev YA. Early Türks: Essays on the history and ideology. Dyke-Press. Australia; 2002. p. 338.

197. Simonenko AV. Sarmatian horsemen of Northern Black Sea. Nestor History. Russia; 2010. p. 308.

198. Nefiodkin AK. Military Sarmatians and Alans (according to ancient sources). StPb Nestor History; Russia; 2011. p. 304.

199. Novozhenov VA. Early Andronovo chariot's innovation and some aspects of the genesis of Chinese civilization. Eurasian steppe cultures and their interaction with the ancient civilizations, Proceedings of the international scientific conference devoted to 110 - year anniversary of the outstanding Russian archaeologist MP Gryaznov T2. Publishing House IHMC, Russia; 2012b. p. 183-187.

200. Novozhenov VA. On the identification of the tamgashaped marks in the petroglyphs of Central Asia. Historical and cultural heritage and contemporary culture. Coll Materials of the international seminar. Almaty Institute of Culture. Russia; 2012c. p. 117-122.

201. Novozhenov VA. Notes on ethnic and cultural history of the Bronze Age tribes of Central Asia. In: Zhumataev R, editor. Materials and Research on kulturogenetic processes on the territory of the ancient and medieval Kazakhstan. Field materials and research department of archeology, ethnology and museology Kazakh National University named Al-Farabi vol 2, Kazak university, Kazakhstan; 2012d. p. 44-67.

202. Novozhenov VA. Indo-European communication in the light of the spread of ancient wheeled vehicle: the nomadic model of the motherland home Materials and Research on kulturogenetic processes in the Bronze Age and Early Nomads, Materials of Conference and the round table «The traditional culture of Kazakhs (questions of genesis and continuity) to mark the 60th anniversary of Prof T Toleubayev. The research department of archeology, ethnology and museology Kazakh National University AlFarabi Vol 4, Kazak university, Kazakhstan; 2013. p. 19-71.

203. Novozhenov VA. A model of Turkic communication and the formation of their own identity. Western Turk Qaganate Atlas. Kazakhstan; $2013 \mathrm{~b}$ p. 132-142.

204. Novozhenov VA. Altynbekov K. To a question about the use of chariots in the era of Early Nomads. In: Baytanaev BA, Baipakov K, editors. The ascent to the heights of archeology. Collected materials of the international scientific conference «Ancient and medieval States on the territory of Kazakhstan», dedicated to the 90th anniversary of KA Akishev, Institute of Archaeology, Kazakhstan; 2014. p. 231-247.

205. Novozhenov I. Adaptability of the Beauty. Sociobiological analysis of Beauty. Bank of cultural information. Russia; 2005. p. 534.

206. Over 2200 year unsolved mysteries of Qin dynasty. China, p. 159.

207. Xiaoshan Q, Wang Bo. The Ancient Culture in Xinjiang Along the Silk Road. Xinjiang, Xinjiang-Uygur Autonomous Region International Cultural Exchange Association, China; 2008. p. 304.

208. Marco P. Transfer from Old French by Minayeff. Introductory article, comment and editorial translation by KI Kunin, Russia; 1940

209. Polidovich YB. Scythian horse and a horse-bridle in the funeral rites of the peoples of the south and eastern Europe. In: Kalganova GY, editor. Text, Context, The subtext, Coll Articles in honor of MN Pogrebova. M Institute of Oriental Studies, Russia; 2013. p. 157-227.

210. Rawlinson G. The Seven Great Monarchies of the Ancient Eastern World or the History, Geography and Antiquities of Chaldaea, Assyria Babylon, Media, Persia, Parthia and Sassanian or New Persian Empire. John W Lovell company. USA; 1880. p. 680.

211. Reade JE. Assyrian Sculpture. British Museum Press. UK; 2011. p. 96.

212. Rudenko SI. Fifth Pazyryk Barrow. KSIIMK. 1951;37:106-116.

213. Rudenko SI. Culture population of Gorny Altai in Scythian time. ML Nauka. Russia; 1953. p. 344. 
214. Rudenko SI. Culture of the population of the Central Altai in Scythian time. ML Nauka. Russia; 1960

215. Rumyantsev EA. Restoration and preservation of ancient wooden carts from the Caucasus and Altai. SA; 1961. p. 236-242.

216. Samashev Z. Berel Almaty. Taimas. Kazakhstan; 2011. p. 194.

217. Samashev Z, Zhang Ho, Bokovenko N, et al. Rock Art of Kazakhstan. Foundation History of Northeast Asia, Astana branch of the Institute of Archaeology, Kazakhstan; 2011.

218. Stepanova EV. Saddles from Third Pazyryk mound. In: Aliokshin VA, et al. editor. Eurasian steppe cultures and their interaction with the ancient civilizations, Proceedings of the international scientific conference devoted to 110 - year anniversary of the outstanding Russian archaeologist MP Gryaznov. Publishing House IHMC, Russia; 2012. p. 446-453.
219. Tasmagambetov I. Centaurs of Great Steppe. Berel Foundation, Kazakhstan; 2003. p. 487.

220. Varfolomeev V. Kent the city of the Bronze Age. New research in the era of independence. In: Baytanaev BA, editor. Муңzhyldyқtar kuəlary: Kazakhstan archeology ғylymy 20 zhylda (1991-2011): ғуlymi maқalalar zhinaғy. Almaty Institute of Archaeology.Kazakhstan; 2011. p. 85-96.

221. Walczak SB. Classification and composition of Scythian complexes with sets of draft harness. In: Moshkova MG, editor. Problems of modern archeology, Coll Memory VA Bashilov. Russia; 2008. p. 75-87.

222. Walczak SB. Saddlery in the first third of the I mill. BC in the South Eastern Europe. M Taus. Russia; 2009. p. 234.

223. Werner FD. Matheson SA Persia. Persepolis. Iran; 2001. p. 104 